Research Article

\title{
Evaluation of pressure ulcer development and follow-up in Covid-19 patients followed in pandemic intensive care units
}

Pandemi yoğun bakım ünitelerinde takip edilen Covid-19 hastalarında basınç ülseri gelişimi ve takibinin değerlendirilmesi

\section{Halit Baykan ${ }^{\mathrm{a}}$}

${ }^{a}$ Department of Plastic, Reconstructive and Aesthetic Surgery, Ministry of Health, Kayseri City Research and Training Hospital, Kayseri, Turkey

\begin{abstract}
Introduction: Pressure ulcers occur in areas with bony protrusions exposed to pressure. Its incidence is between $1.6 \%$ and $49 \%$. Due to respiratory failure in Covid-19, patients are frequently followed up in intensive care units. Some of the patients are intubated, and respiratory support is provided with a ventilator. The risk of developing pressure sores increases in patients followed for a long time on a ventilator. This study was conducted to investigate the frequency of pressure ulcers in Covid-19 patients.

Methods: Patients followed up in Covid-19 intensive care (ICU) units in Kayseri City Training and Research Hospital between March and November 2020 and developed pressure ulcers were included in the study. Patient data were collected retrospectively using electronic health records.

Results: A total of 4922 patients were followed up in intensive care units, 2010 patients were intubated, and 1332 patients died. Only 51 patients had pressure ulcers at various stages.

Conclusion: Pressure ulcers in Covid-19 patients are seen mainly in the elderly and people with underlying chronic diseases. Besides, the probability of pressure ulcers in this group was less than in other patients. Furthermore, nursing care is critical in intensive care units.

Keywords: Intensive care unit, Pressure ulcer, Covid
\end{abstract}

$\ddot{O} \mathbf{z}$

Giriş: Basınç ülseri basınca maruz kalan kemik çıkıntıların olduğu alanlarda oluşur. Görülme sıklığı \%1,6-\%49 arasındadır. COVID-19 hastalığına bağlı olarak gelişen akciğer yetmezliği nedeniyle hastalar sıklıkla yoğun bakım ünitelerinde takip edilmektedir. Hastaların bir kısmı solunum yetersizliği nedeniyle entübe edilerek ventilatör ile solunum desteği sağlanmaktadır. Uzun süre ventilatör takibi yapılan hastalarda bası yarası gelişme riski artmaktadır. Bu çalışmada Covid-19 hastalarında basınç ülserlerinin sıklığının araştırılması amaçlanmıştır.

Yöntem: Kayseri Şehir Eğitim ve Araştırma Hastanesinde Mart-Kasım 2020 arasında Covid-19 yoğun bakım (YB) ünitelerinde takip edilen ve bası ülseri gelişen hastalar çalışmaya alındı. Hastaların verileri geriye doğru tarandı, bilgisayar ve dosyalardan elde edilen veriler değerlendirilerek çalışmaya alındı.

Bulgular: Yoğun bakımlarda toplam 4922 hasta takip edildi, 2010 hasta entübe edildi ve 1332 hasta ex oldu. Sadece 51 hastada çeşitli evrelerde basınç ülseri görüldü.

Sonuç: Çalışmamızdan üç önemli sonuç çıkarılmıştır. Birincisi, basınç ülserleri Covid-19'lu hastalarda, çoğunlukla yaşlı ve altta yatan kronik hastalığı bulunan kişilerde görülmektedir. İkincisi, basınç ülserleri Covid-19 hastalarında, Covid-19 dışı hastalara göre daha az görülmektedir. Üçüncüsü, Yoğun bakım ünitelerinde hemşirelik bakımı oldukça önemlidir.

Anahtar kelimeler: Yoğun Bakım Ünitesi, Basınç ülseri, Covid

\begin{tabular}{|c|c|c|c|c|}
\hline Received & Accepted & Published Online & Corresponding Author & E-mail \\
\hline February 19, 2021 & May 3, 2021 & May 5, 2021 & Halit Baykan, M.D. & $\underline{\text { halitbaykan@gmail.com }}$ \\
\hline Correspondence & $\begin{array}{l}\text { Dr. Halit Baykan, Kayseri Şehir Eğitim ve Araştırma Hastanesi, Şeker Mah. Muhsin Yazıcıŏlu Bul. } \\
\text { No:77 Kocasinan/Kayseri, Turkey }\end{array}$ \\
\hline
\end{tabular}




\section{Introduction}

Pressure ulcers are localized tissue damage in the skin and subcutaneous tissues due to pressure, friction, tearing, and other factors in areas exposed to pressure. Pressure ulcers are divided into 4 stages by the European Pressure Ulcer Advisory Panel (EPUAP) [1]. These stages are essential in detecting and planning the treatment of ulcers.

Stage 1: There is a non-spotting rash in a localized area, usually over bony prominences.

Stage 2: A loss of partial-thickness dermis, manifesting as a scaleless, red-pink wound, open ulcer. Bullae may develop.

Stage 3: Loss of full-thickness tissue. Subcutaneous fat may be visible, but bone, tendon, or muscles are not exposed. Dead skin may be present but does not hide the depth of tissue loss.

Stage 4: Full thickness tissue loss together with exposed bone, tendon, or muscle is present. There may be abrasions or scabs in some parts of the wound [2].

The development of pressure sores is a complex event. There are risks related to the patient and risks independent of the patient. Patient-related risks are age, weight, ethnicity, comorbidity, impaired tissue perfusion (low $\mathrm{Hb}$, low blood pressure, and sedation), hypothermia, low albumin level, blood glucose level, and general condition of the patient (sensory impairment, coma, and incontinence). Risks independent of the patient are pressure exposure, duration of the pressure, humidity, limitation of daily activities, frequency of changing positions, friction, and tearing [3]. Most patients with the risk of developing pressure ulcers are patients with spinal cord injuries, geriatric patients, hospitalized patients who have undergone orthopedic surgery, and patients followed up in intensive care units [4].

In clinical, prospective, and prevalence studies, the frequency of pressure ulcers is between $1.6 \%$ and $26.8 \%$. In two different studies conducted in Turkey, pressure ulcer rates were $5.8 \%$ and $10.4 \%$ [3]. Due to respiratory failure in Covid-19, patients are frequently followed in intensive care units. Some of the patients are intubated due to respiratory failure, and respiratory support is provided with a ventilator. The risk of developing pressure sores increases in patients who are under ventilator follow-up for a long time.

Covid-19 can cause acute respiratory distress syndrome (ARDS). It was first detected in China in December 2019. It quickly spread all over the world and turned into a pandemic [5,6]. While many affected people have mild symptoms, ARDS can develop in the elderly and people with chronic diseases [7, 8, 9]. These patients are followed in intensive care units. Most of the patients followed in intensive care can be treated with non-invasive ventilation systems (normal oxygen mask, increasing oxygen saturation with prone position, reservoir mask, and high-flow oxygen mask). Endotracheal intubation is required in $5 \%$ of these intensive care patients [10,11]. Pressure ulcer development increases when there is any disruption in intensive care follow-up of intubated patients, such as lack of nursing care, lack of hygiene, lack of nutrition, progression of comorbidities, and advanced age.

This study was planned to retrospectively investigate pressure ulcers (PU) developed in our intensive care patients, who were followed up between March and November 2020 during the covid-19 pandemic.

\section{Methods}

Covid-19 patients hospitalized between March and November 2020 in the Kayseri City Training and Research Hospital and followed up in intensive care (ICU) units were included in the study.

Among the ICU patients, patients with pressure ulcers were selected (Figure 1). Patients were evaluated regarding age, gender, comorbidity, polymerase chain reaction (PCR+), intubation status, localization and stage of pressure sores, and applied treatments.

Obtained data were analyzed with the SPSS 22.0 (SPSS Inc., Chicago, Ill., USA) and MedCalc 18.0 (MedCalc Software bvba, Ostend, Belgium) statistical package programs. Descriptive statistics of numerical variables were presented as mean \pm standard deviation, while categorical variables were expressed as frequency (n) and percentage (\%). Whether the data conformed to the normal distribution was evaluated by the KolmogorovSmirnov or Shapiro-Wilk-Test. The Pearson's Chi-square test or Fisher's exact Chi-square test was used to analyzing categorical data. Quantitative data were compared using the Student's t-test or Wilcoxon test. $\mathrm{P}<0.05$ was considered statistically significant (Table 1 ).
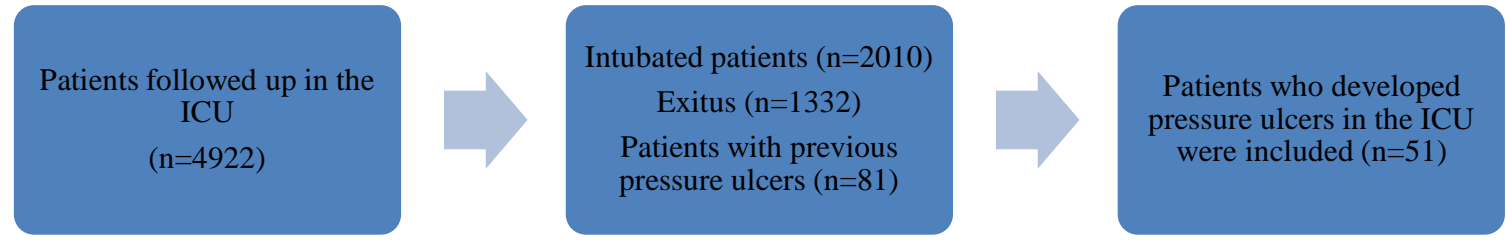

Figure 1. Patient flow diagram

\section{Ethical approval, informed consent, and permissions}

This study was conducted with the approval of the Kayseri City Training and Research Hospital Ethics Committee dated 18/02/2021 and numbered 300 . 


\section{Results}

Table 2 shows Covid-19 patient numbers. A total of 166,748 patients applied to the hospital outpatient clinics. 32,814 patients were hospitalized and treated. Of these patients, 4,922 were followed up in intensive care units, and 2010 were intubated. In 51 of the intubated patients, pressure sores developed in various parts of the body at different stages. During this follow-up period, a total of 1332 patients died. It was seen that the highest PU was seen in the Anesthesia ICU, followed by Internal Medicine ICU and other ICUs (Figure 2).

It was observed that there were 26 female patients and 25 male patients in the distribution of patients according to gender (Figure 3 ). In the classification according to PU stages, it was observed that there were thirty-one patients in Stage 2, eighteen in Stage 1, and two patients in Stage 3. No patients were seen in Stage 4 (Figure 4).

The most common distribution regions of the pressure ulcers were the sacrum region, heels, trochanteric regions, back region, scapular region, ears, occipital region, and other regions, respectively (Figure 5).

Mortality rates in the Covid-19 ICU units were $27.06 \%$. This proportion was $20.30 \%$ in non-Covid-19 ICU units.

Table 1. Comparison of demographic data between the groups

\begin{tabular}{|c|c|c|c|c|c|}
\hline \multicolumn{6}{|c|}{ Demographic data of patients with pressure ulcers in the Covid-19 intensive care unit and outside the intensive care unit } \\
\hline & & All Diseases $(n=132)$ & O-ICU Group $1(n=81)$ & C-ICU Group $2(n=51)$ & P value \\
\hline \multicolumn{2}{|c|}{ Age $($ mean \pm SD) } & $72.56 \pm 13.87$ & $70.53 \pm 15.85$ & $73.84 \pm 12.41$ & 0.183 \\
\hline \multicolumn{6}{|c|}{ Sex } \\
\hline & Male $\mathrm{n}(\%)$ & $70(53.0)$ & $46(56.8)$ & $25(47.1)$ & - \\
\hline & Female $\mathrm{n}(\%)$ & $62(47.0)$ & $35(43.2)$ & $26(52.9)$ & - \\
\hline \multicolumn{6}{|c|}{ Chronic Diseases } \\
\hline & Hypertension & $48(36.4)$ & $35(43.2)$ & $13(25.5)$ & 0.043 \\
\hline & Diabetes & $22(16.7)$ & $21(25.9)$ & $1(2.0)$ & $<0.001$ \\
\hline & Heart disease & $9(6.8)$ & $3(3.7)$ & $6(11.8)$ & 0.088 \\
\hline & COPD & $14(10.6)$ & $7(8.6)$ & $7(13.7)$ & 0.393 \\
\hline & CVD & $7(5.3)$ & $2(2.5)$ & $5(9.8)$ & 0.107 \\
\hline & Alzheimer & $25(18.9)$ & $20(24.7)$ & $5(9.8)$ & 0.034 \\
\hline & Parkinson's & $15(11.4)$ & $13(16.0)$ & $2(3.9)$ & 0.033 \\
\hline & Asthma & $4(3.0)$ & $4(4.9)$ & - & - \\
\hline & Epilepsy & $5(3.8)$ & $3(3.7)$ & $2(3.9)$ & 0.949 \\
\hline \multicolumn{6}{|c|}{ Wound Location } \\
\hline 1 & Sacrum & $39(29.5)$ & $34(42.0)$ & $22(43.13)$ & - \\
\hline 2 & Heel & $20(15.2)$ & $11(13.6)$ & $7(13.72)$ & - \\
\hline 3 & Trochanter & $9(6.8)$ & $8(9.9)$ & $2(3.92)$ & - \\
\hline 4 & Scapula & $5(3.8)$ & $3(3.7)$ & $2(3.92)$ & - \\
\hline 5 & Back & $6(4.5)$ & $4(4.9)$ & $1(1.96)$ & - \\
\hline 6 & Ears & $6(4.5)$ & $2(2.5)$ & $1(1.96)$ & - \\
\hline 7 & Other areas & $47(35.6)$ & $19(23.5)$ & $16(32.05)$ & - \\
\hline \multicolumn{6}{|c|}{ Wound Properties } \\
\hline & Size, median (min-max) & $7.5(1-105)$ & $9(1-105)$ & $6(1-100)$ & 0.266 \\
\hline \multicolumn{6}{|c|}{ Stage } \\
\hline & Stage 1 & $51(38.6)$ & $30(37.0)$ & $21(41.2)$ & - \\
\hline & Stage 2 & $72(54.5)$ & $43(53.1)$ & $29(56.9)$ & - \\
\hline & Stage 3 & $9(6.8)$ & $8(9.9)$ & $1(2.0)$ & - \\
\hline \multicolumn{6}{|c|}{ Laboratory Values } \\
\hline & WBC & $15.99 \pm 16.13$ & $17.75 \pm 19.10$ & $13.20 \pm 9.22$ & 0.001 \\
\hline & $\operatorname{Hbg}(\mathrm{d} / \mathrm{dl})$ & $10.67 \pm 2.11$ & $10.75 \pm 1.90$ & $10.54 \pm 2.41$ & 0.580 \\
\hline & ALB (gr/l) & $22.89 \pm 4.47$ & $22.22 \pm 4.6$ & $23.96 \pm 4.03$ & 0.030 \\
\hline \multicolumn{6}{|c|}{ Hospitalized Clinics } \\
\hline & Anesthesia ICU & $22(16.7)$ & $14(17.3)$ & $14(27.4)$ & - \\
\hline & Neurosurgery ICU & $19(14.4)$ & $18(22.2)$ & $1(1.96)$ & - \\
\hline & Internal Medicine ICU & $29(22.0)$ & $10(12.3)$ & $11(21.56)$ & - \\
\hline & General ICU & $4(3.0)$ & $4(4.9)$ & $1(1.96)$ & - \\
\hline & Chest Diseases ICU & $19(14.4)$ & $13(16.0)$ & $4(7.84)$ & - \\
\hline & Stroke ICU & $27(20.5)$ & $16(19.8)$ & $6(11.76)$ & - \\
\hline & Pandemic ICU & $12(9.1)$ & $6(7.4)$ & $2(3.92)$ & - \\
\hline & Other ICU & & & $11(21.56)$ & \\
\hline
\end{tabular}

SD: Standard deviation, COPD: Chronic obstructive pulmonary disease, CVD: Cerebrovascular disease, WBC: White blood cell count, Hbg: Hemoglobin, ALB: Albumin, O-ICU: Other ICU, C-ICU: Covid-19 ICU 
Table 2. Patients followed in the pandemic between 11.03.2020 and 31.11.2020

\begin{tabular}{lc}
\hline & Pandemic Patients \\
\hline Outpatients & 166748 \\
Inpatients & 32814 \\
Intensive Care Patients & 4922 \\
Intubated Patients & 2010 \\
Intensive Care Pressure Ulcer & 51 \\
Patients Died & 1332 \\
\hline
\end{tabular}

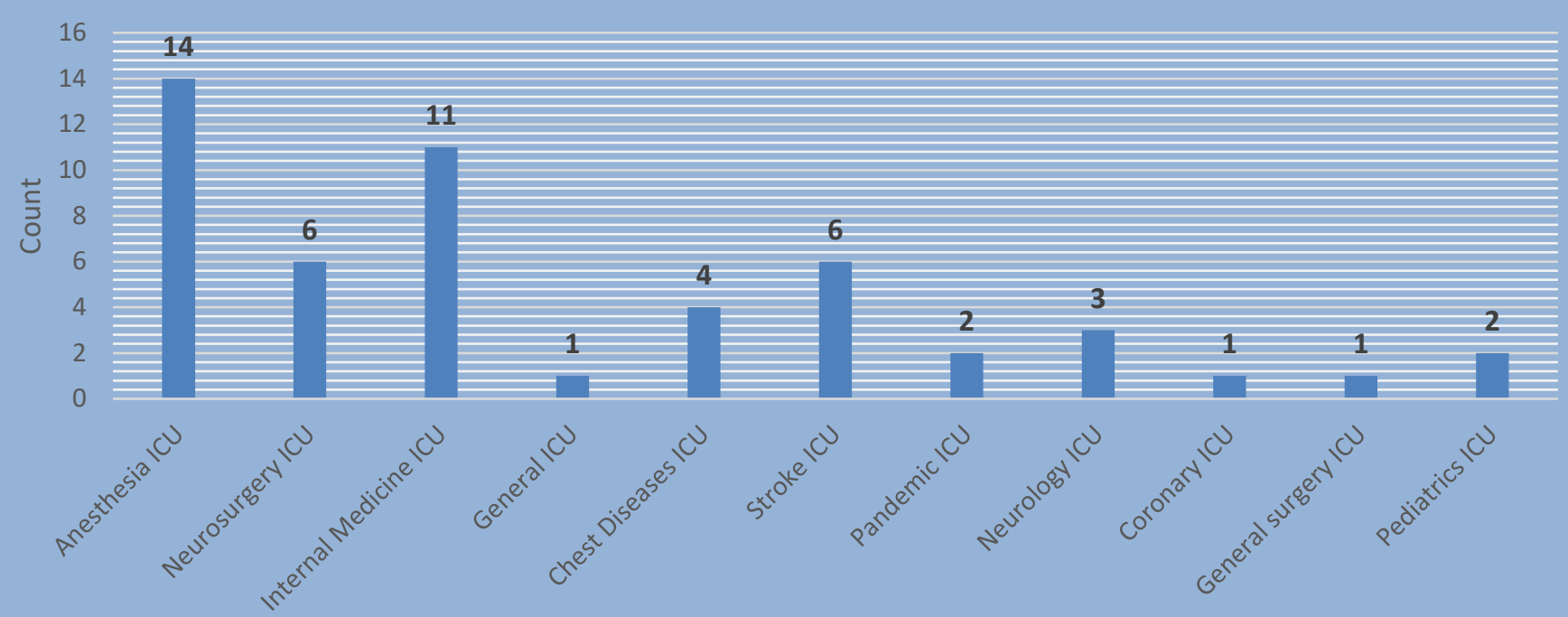

Figure 2. Intensive care services distribution in pressure sore patients diagnosed with COVID

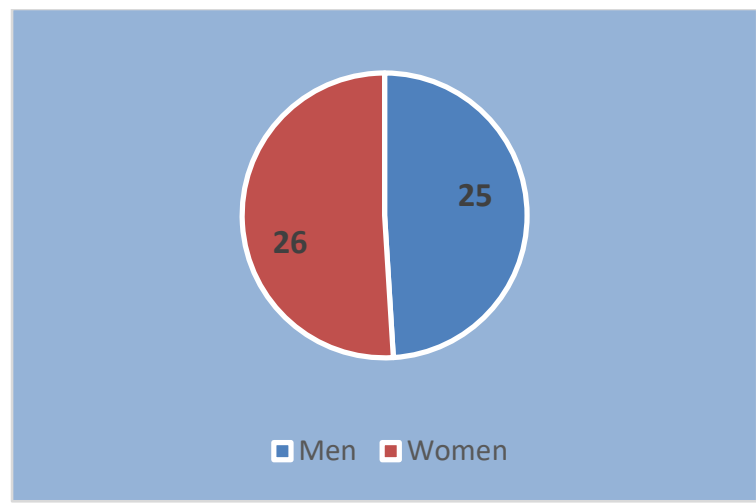

Figure 3. Distribution of pressure sores by gender

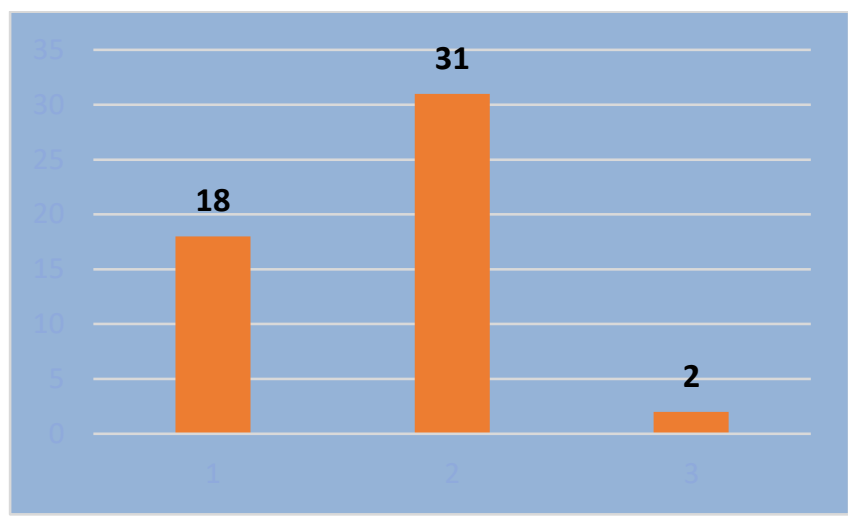

Figure 4. Covid-19 patients' pressure sores by stage distribution

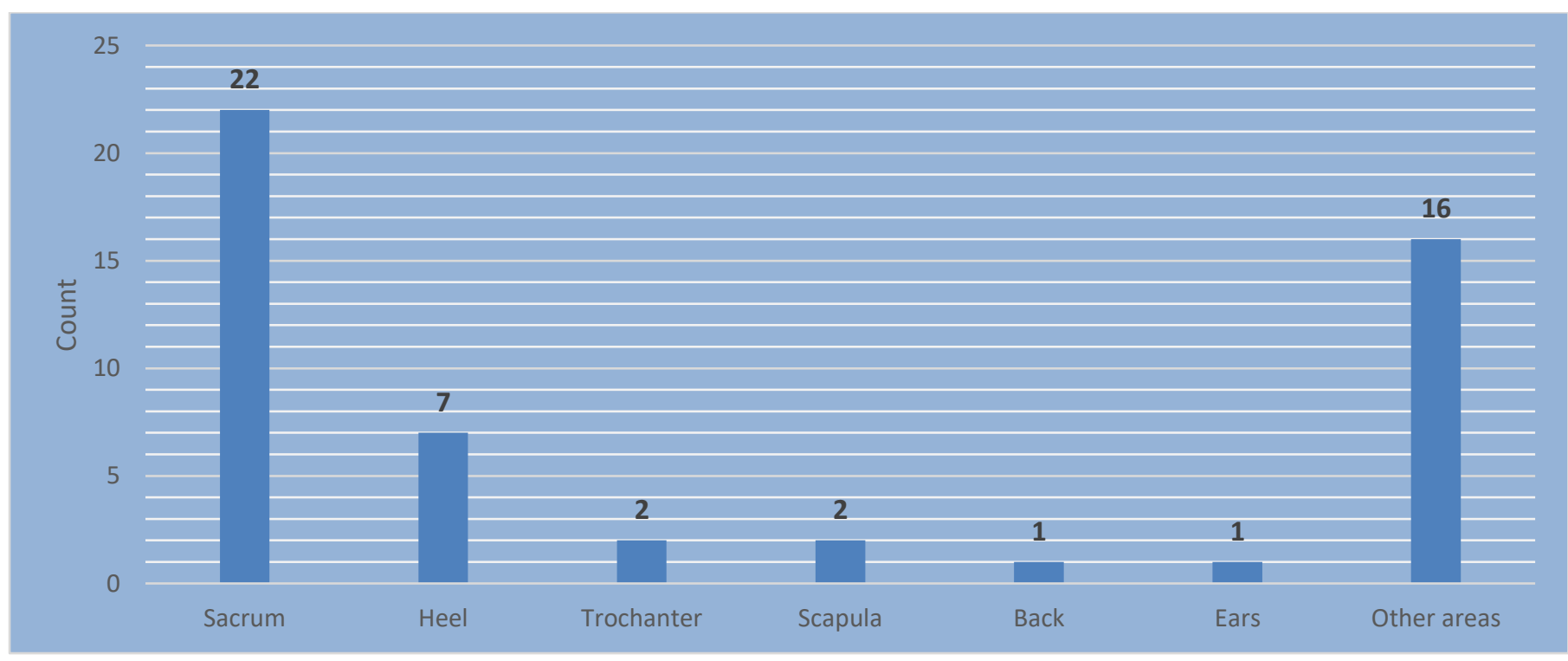

Figure 5: Distribution of pressure sores by body area 


\section{Discussion}

Pressure ulcers are usually caused by the exposure of soft tissues over bony prominences in the body to pressure [12]. Non-Covid-19 pressure ulcers develop mostly in the sacral region and heel area [11]. In our study, in Covid-19 patients with pressure ulcers outside the ICU, the most pressure ulcers were at the sacrum region, heels, trochanteric regions, scapular region, ears, occipital region, and others. The same sequence was followed in patients who developed pressure ulcers after entering the ICU. This sequence was consistent with the literature (11) (Table 1).

The prevalence of pressure ulcers in intensive care units is in the order of anesthesia ICU, internal medicine ICU, stroke ICU, and others. This is because these units are the first intensive care units used in our hospital during the pandemic. As the pandemic patients increased, other intensive care units started to be used respectively. ICUs converted into the first pandemic intensive care units have received the most patients, which is the reason for the incidence difference.

In prevalence studies conducted in European countries, pressure ulcer rates have been determined in hospitalized non-covid-19 patients, especially in intensive care units, as $14 \%$ in Italy, $4 \%$ in Denmark, 38\% in the Netherlands, and 49\% in Germany [4]. In two different non-covid-19 studies conducted in Turkey, these rates were $5.8 \%$ and $10.4 \%$ [3]. In our study, this rate was $1.03 \%$ in patients with covid-19. On the other hand, our one-year non-covid-19 pressure ulcer data average is 3.07\%. These rates are lower than studies conducted in European countries and Turkey.

When we classified pressure ulcers according to their stages, it was observed that the most pressure ulcers were in Stage 2, followed by Stage 1 and Stage 3 ulcers. Stage 4 pressure ulcers were almost never seen. The rapid progression of the patients with Covid-19 after being intubated in intensive care units and early death prevent the progression of pressure ulcers.

There is no highly effective method in the treatment of pressure ulcers. The primary step of the treatment is pressure relief. Necrotic tissues act as a barrier preventing wound contraction and epithelization. They also create a focus for infection [14]. If there is necrotic tissue, debridement can be done surgically, mechanically, osmotic, chemical, and autolytic or enzymatically $[15,16]$. However, the most effective method is surgical debridement. Nevertheless, vaporization with carbon dioxide laser is very successful in soft tissue as well as in bony areas. The wet-to-dry dressing is a highly effective technique in the debridement of remaining necrotic fragments [14]. Surgical, mechanical, chemical debridement, and wet-todry dressing were mostly performed in our patients.

Four factors increase the formation of pressure ulcers: exposure of the tissues to prolonged pressure, exposure to shearing, tear, and moisture. The pressure in the capillary regions of the tissues is between $12-32 \mathrm{mmHg}$. Ischemic changes emerge when the tissues are exposed to a pressure above capillary pressure for a long time [13]. In experimental studies conducted by Kosiak et al., a constant pressure of $70 \mathrm{mmHg}$ applied to a tissue continuously for 2 hours causes irreversible changes. On the other hand, minimal tissue change occurs if a pressure greater than $240 \mathrm{mmHg}$ is used intermittently [13]. To prevent ulcers in the areas exposed to pressure in immobile patients in the ICU units, a change of position is required every 2 hours [14].

Our experienced healthcare personnel made it a routine to re-position the patients bi-hourly to prevent pressure ulcers. At the same time, attention paid to patients while positioning and changing the bed sheet is critical. Changing the bedsheet frequently when necessary to keep the patients' beds dry also prevents pressure ulcers. As a result, pressure ulcers are less common in our patients.

Undoubtedly, the value of intensive care units and nursing care is very important in the development of pressure ulcers. Pressure ulcer indicators demonstrate the quality of a hospital's intensive care units and nursing care [3]. Our ICU units are modern and equipped $3^{\text {rd }}$-level intensive care units. Since the healthcare staff working in our ICU units are trained and experienced, our pressure ulcer rates were low (1.03\%). This is a very significant proportion.

This study demonstrated that the duration of stay in patients hospitalized in non-Covid-19 ICU units was 10-11 days, while the duration of patients in Covid-19-ICU units was 6-7 days on average. In ICU units, pressure ulcers in Covid-19 patients were less frequent than those in the non-Covid19 patients. Since Covid-19 progression is rapid in patients hospitalized in the ICU, patients may die before pressure ulcers can develop. This explains the low rates of pressure ulcers. Moreover, pressure ulcer rates in our non-covid-19 ICU patients were lower than those seen in European countries [4]. Mortality in Covid-19 ICU patients was 27.06\%. In our non-Covid-19 ICU units, this rate has been determined as $20.30 \%$.

\section{Conclusion}

The Covid-19 pandemic is the biggest disaster we have experienced in recent years. During this process, the whole world was affected, and the mobility between countries was interrupted. The Covid-19 mostly affected the elderly and people with underlying chronic diseases. The lungs were mostly affected, and the patients were followed in the ICU units due to respiratory distress. Patients who develop ARDS become immobile by getting connected to a ventilator. As a result, pressure ulcers are observed in patients. Depending on the course of the disease in the ICU units, patients either improve and are transferred to regular inpatient services or develop ARDS and are connected to a mechanical ventilator. Pressure ulcers develop in patients who are intubated. These patients mostly die rapidly. In our Covid-19 ICU units, the duration of stay in the ICU unit was shorter than the duration of stay in our non-Covid-19 ICU units. Patients stay shorter in ICU units due to Covid-19, which explains our lower pressure ulcer rates. High-quality nursing care in the ICU units has decreased pressure ulcers, which is a significant parameter. Establishing wound care teams in ICU units in all hospitals and training and supervising healthcare personnel will reduce the incidence of pressure ulcers. 
Conflict of interest: The authors declare no conflict of interest.

Financial support: No financial support has been received.

\begin{tabular}{|r|r|l|}
\hline \multicolumn{2}{|c|}{ Author Contributions } & Author Initials \\
\hline SCD & Study Conception and Design & HB \\
\hline AD & Acquisition of Data & HB \\
\hline AID & Analysis and Interpretation of Data & HB \\
\hline DM & Drafting of Manuscript & HB \\
\hline CR & Critical Revision & HB \\
\hline
\end{tabular}

Prior publication: This study has not been previously published in any journal and has not been presented at congresses.

\section{References}

1. Defloor T, Schoonhoven L, Fletcher J, Furtado K, Heyman HW, Lubbers MJ, et al. Statement of the European Pressure Ulcer Advisory PanelPressure Ulcer Classification: Differentiation Between Pressure Ulcers and Moisture Lesions. J Wocn. 2005;32(5):302-6. https://doi.org/10.1097/00152192-200509000-00006

2. Cox J. Predictors of pressure ulcers in adult critical care patients. Am J Crit care. 2011;20(5):364-75. https://doi.org/10.4037/ajcc2011934

3. Karahan A, Abbasoğlu A, Işı SA, Çevik B, Saltan Ç, Elbaş NÖ, et al. Factors Affecting Wound Healing in Individuals With Pressure Ulcers: A Retrospective Study. Ostomy Wound Manage. 2018;64(2):32-9. https://pubmed.ncbi.nlm.nih.gov/29481325/

4. Shahin ESM, Dassen T, Halfens RJG. Pressure ulcer prevalence in intensive care patients: a cross-sectional study. J Eval Clin Pract. 2008;14(4):563-8. https://doi.org/10.1111/j.1365-2753.2007.00918.x

5. Wang C, Horby PW, Hayden FG, Gao GF. A novel coronavirus outbreak of global health concern. Lancet. 2020;395(10223):470-3. https://doi.org/10.1016/S0140-6736(20)30185-9

6. Wu Z, McGoogan JM. Characteristics of and important lessons from the coronavirus disease 2019 (COVID-19) outbreak in China: summary of a report of 72314 cases from the Chinese Center for Disease Control and Prevention. Jama. 2020;323(13):1239-42. https://doi.org/10.1001/jama.2020.2648

7. Guan W, Ni Z, Hu Y, Liang W, Ou C, He J, et al. Clinical characteristics of coronavirus disease 2019 in China. N Engl J Med. 2020;382(18):1708-20. https://doi.org/10.1056/NEJMoa2002032

8. Wang D, Hu B, Hu C, Zhu F, Liu X, Zhang J, et al. Clinical characteristics of 138 hospitalized patients with 2019 novel coronavirus-infected pneumonia in Wuhan, China. Jama. 2020;323(11):1061-9. https://doi.org/10.1001/jama.2020.1585

9. Liu X, Zhou H, Zhou Y, Wu X, Zhao Y, Lu Y, et al. Risk factors associated with disease severity and length of hospital stay in COVID-19 patients. J Infect. 2020;81(1):e95-7. https://doi.org/10.1016/j.jinf.2020.04.008

10. Phua J, Weng L, Ling L, Egi M, Lim C-M, Divatia JV, et al. Intensive care management of coronavirus disease 2019 (COVID-19): challenges and recommendations. Lancet Respir Med. 2020;8(5):506-17. https://doi.org/10.1016/S2213-2600(20)30161-2

11. Meng L, Qiu H, Wan L, Ai Y, Xue Z, Guo Q, et al. Intubation and ventilation amid the COVID-19 outbreak: Wuhan's experience. Anesthesiology. 2020;132(6):1317-32. https://doi.org/10.1097/ALN.0000000000003296

12. Terekeci H, Kucukardali Y, Top C, Onem Y, Celik S, Öktenli Ç. Risk assessment study of the pressure ulcers in intensive care unit patients. Eur J Intern Med. 2009;20(4):394-7. https://doi.org/10.1016/j.ejim.2008.11.001

13. Herman LE, Rothman KF. Prevention, care, and treatment of pressure (decubitus) ulcers in intensive care unit patients. J Intensive Care Med. 1989;4(3):117-23. https://doi.org/10.1177/088506668900400306

14. Yarkony GM. Pressure ulcers: a review. Arch Phys Med Rehabil. 1994;75(8):908-17. https://doi.org/10.1016/0003-9993(94)90117-1

15. Witkowski JA, Parish LC. Debridement of cutaneous ulcers: medical and surgical aspects. Clin Dermatol. 1991;9(4):585-91. https://doi.org/10.1016/0738-081X(91)90088-3

16. Baxter CR, Rodeheaver GT. Interventions: hemostasis, cleansing, topical antibiotics, debridement and closure. In: Eaglstein WH, editor. New directions in wound healing. Princeton, NJ: ER Squibb \& Sons, Inc.; 1990. p. 71-82. 